\title{
The Effect of Layered Flipped Learning Model on Academic Success
}

\author{
Burcu Ökmen * \\ Duzce University, Education Faculty, Turkey \\ ORCID: 0000-0002-0296-0078
}

\begin{tabular}{|c|c|}
\hline & $\begin{array}{l}\text { Abdurrahman Kiliç } \\
\text { ce University, Education Faculty, Turkey } \\
\text { ORCID: O000-0002-2704-2951 }\end{array}$ \\
\hline Article history & \multirow{8}{*}{$\begin{array}{l}\text { The purpose of this study is to determine how students' academic } \\
\text { achievement in English lessons improved when the layered flipped } \\
\text { learning model is used in these lessons and what the students' views } \\
\text { about the tasks chosen and performed within the scope of this model are. } \\
\text { One of the qualitative research methods, the 'action research' method was } \\
\text { used in this research. The research was conducted with the fifth grade of } \\
\text { a secondary school in the West Black Sea region of Turkey in the } \\
2017 / 2018 \text { academic year. In the research process, readiness test, } \\
\text { achievement test, focus group interview, task evaluation form, reflective } \\
\text { daily form-course video recordings were used as data collection tools. } \\
\text { The data obtained from the focus group interview at the end of the action } \\
\text { plans were analyzed using the content analysis method. The readiness test } \\
\text { and the achievement tests were tabulated separately to show the } \\
\text { development of each student in the process and the class averages. } \\
\text { According to the results of the research, it was seen that the layered } \\
\text { flipped learning model had a positive effect on students' academic } \\
\text { achievement and that their academic achievement increased gradually in } \\
\text { all of their reading, listening and speaking skills. According to the results } \\
\text { of the research, a number of suggestions were made. }\end{array}$} \\
\hline $\begin{array}{l}\text { Received: } \\
19.10 .2020\end{array}$ & \\
\hline $\begin{array}{l}\text { Received in revised form: } \\
08.02 .2021\end{array}$ & \\
\hline $\begin{array}{l}\text { Accepted: } \\
12.02 .2021\end{array}$ & \\
\hline Key words: & \\
\hline $\begin{array}{l}\text { Layered flipped learning } \\
\text { model; }\end{array}$ & \\
\hline $\begin{array}{l}\text { Academic success; } \\
\text { Action research; }\end{array}$ & \\
\hline e teaching & \\
\hline
\end{tabular}

\section{Introduction}

Today, in addition to student-centered approaches, the effective use of information technologies that bring mobility to learning and teaching processes has gained importance, and the use of new technologies in education has thus made the learning and teaching processes more enjoyable by facilitating learning and teaching activities (Pala, 2006). One of the learning models that adopt technology and student-centered understanding is the flipped learning model.

The flipped learning model is a part of a broad instructional movement that includes blended learning, inquiry-based learning and other instructional approaches, and includes flexible, effective tools for greater integration of learners (Johnson, Becker, Estrada \& Freeman, 2014). This model is a pedagogical approach emphasizing the formation of a student-centered

\footnotetext{
* Correspondency: burcuokmen91@ @otmail.com
} 
learning environment and student attendance with the use of instructional and cooperative learning (McCallum et al., 2015).

In the flipped learning model, the students watch the course videos and other e-materials prepared by the instructor before the lesson and complete the low-level cognitive activities and form the basic knowledge and concepts before coming to school. Students assimilate the subject with different active learning activities in the classroom (Bishop \& Verlager, 2013). As the biggest barrier preventing active learning environments where students can learn by experience in class, the problem of time constraints can be solved and additional time can be provided by means of this model (Baker, 2000). Students acquire low-level information outside the classroom through technology, and use high-level thinking skills with teachers and classmates in the classroom (Bergmann \& Sams, 2012). According to Berret (2012) with this model, students have the opportunity to practice what they have learned with both the teacher and their peers through activities such as discussions, projects, and alike in the classroom.

The aim of this model is to provide learning opportunities independent of time, space, and tool and to create active learning environments where interaction is at the forefront (Baker, 2000). O'Neil, Kelly, and Bone (2012) defined flipped learning as a new learning model that positively affected learning environments facilitated by educational technology and direct activities.

To explain flipped learning and to apply it better, 4 basic components were determined by the Flipped Learning Network, consisting of experienced educators, in 2013 (Hamdan et al., 2013). These components were shaped around the theoretical framework of the flipped learning model, as well (Tetreault, 2006). Composing the acronym "F-L-I-P," these components are: 1) Flexible environment, 2) Learning culture, 3) Intentional content, and 4) Professional educators (Hamdan et al., 2013). Flipped learning environments must be flexible learning environments that educators and students can regulate at will. Educators must accept complicated and noisy environments in contrast with quiet and systematic classroom environments (Hamdan et al., 2013; Tetreault, 2006). This model has provided students with the ability to watch, listen, read, and revise subject material many times by removing the constraints of time and place (Enfield, 2013).

\section{Layered Flipped Learning Model}

As a result of the literature review, it was seen that there are both studies showing that the flipped learning model increases academic achievement and attitude, and the studies that state that this model has some drawbacks (Bergmann \& Sams, 2012, 2014; Danişman et. al., 2017; Enfield, 2012; Johnson, 2013; Şahin et. al., 2020; Talbert, 2012; Thoms, 2012). These drawbacks are as follows: it is difficult to motivate students, issues with time management, classroom management issues and not being able to assure the inclusion of students in activities (Şahin et. al., 2020; Talbert, 2012), students who have completed their tasks have to wait for each other (Danişman et. al., 2017; Thoms, 2012), students do not know in advance what they will do, it is not possible to check whether students watch the videos set (Bergmann and Sams, 2012, 2014), students may not want to not participate in group activities (Johnson, 2013), there is no immediate correction of student errors and mistakes (Enfield, 2012). A layered flipped learning model was developed to remove the drawbacks of flipped learning (Ökmen, 2020) and not to neglect the difference in learners' cognitive levels (Liu, Wei \& Gao, 2016). Bergmann and Sams (2014), who developed the model, also recommend that everyone apply and develop this model and contribute to this model. 
Layered flipped learning models developed by Ökmen (2020) and Liu, Wei and Gao (2016) are different. In layered flipped learning model developed by Liu, Wei and Gao (2016), teachers divide the students into five (A, B, C, D, and E) implicit layers through tests, classroom observations, questionnaires. According to the analytical results, teachers prepare for the new lesson together, making different-leveled micro-courses to meet the needs of the students with different bases and demands. Different-leveled micro-courses are labeled as five levels of A, B, C, D, and E, and the students choose to watch the micro-course independently. Learning length and times to play depend on students' willingness and abilities. In this research layered flipped learning model developed by Ökmen (2020) was implemented.

In the layered flipped learning model developed by Ökmen (2020), the teaching process of the flipped learning model is divided into three levels: A, B, and C. This model adopts a studentcentered approach and aims to provide students with skills such as selection, responsibility, and high-level thinking. This model, in which the student is fully responsible for learning, is based on the understanding that each student's learning styles, intelligence dimensions, readiness, and thinking systems are different from each other (Ökmen, 2020).

In the layered flipped learning model, home tasks are arranged according to C-level; class tasks are arranged according to B and A levels. C-level tasks should be prepared as a base for B-level and B-level tasks should be prepared as a basis for A-level. Students are not expected to perform every task on the levels. Students complete tasks according to their interests and try to move on to the next level. Points are assigned to each task. In order for the student to move to the next level, he / she has to get the score determined from the tasks in the level (Ökmen, 2020).

In this model, the teacher first determines the learning objectives and content. Then s/he designs the $\mathrm{C}, \mathrm{B}$ and $\mathrm{A}$ levels. C-level tasks are sent students to complete at home. The students complete the $\mathrm{C}$-level task in a way that is enough to reach the score determined or, if they wish, more C- level tasks can be assigned? according to their interests and needs. Students completing the C-level task select B-level tasks and begin to do it in the classroom. Students who cannot complete the C-level tasks at home are given the opportunity to complete these tasks in the classroom. If they have completed the C-level tasks in the classroom, these students can begin the B-level tasks. Students who complete B-level can also move to the last A-level. The students completing the A-level complete the unit (Ökmen, 2020).

\section{Aims of This Study}

In Turkey, although students study English for many years, the desired success in language learning and language use in an active way cannot be achieved (Memiş \& Erdem, 2013; Paker, 2012). As a reason it can be shown that teachers do not attach importance to teaching the four basic skills in the same way (Akgüzel, 2006; Ökmen \& Kılıç, 2016; 2018), do not use audiovisual materials (Ökmen \& K1lıç, 2018; Paker, 2012), teach the language as a subject to be studied not as a means of communication, and practice applications contrary to the communicative method (Ökmen \& K1lıç, 2016; 2018; Paker, 2012), and students have prejudice and negative attitude towards English lesson (Akgüzel, 2006; Paker, 2012; Topaloğlu, 2012).

In this study, it was thought that students would increase their academic success in this course due to reasons such as the layered flipped learning model's having a student-centered education understanding, its giving the learning responsibility to the student, and students' 
being always active during the process. Ökmen and K1lıç (2020) also stated that this model is effective in developing students' attitudes and self-regulation skills. For this reason in this study, the layered flipped learning model was designed with the consideration of the teaching practices of English lessons. The purpose of this study is to determine how students 'academic achievement in this lesson improved when the layered flipped learning model is used in English lessons and what the students' views about the tasks chosen and performed within the scope of this model are. This basic purpose has searched for answers to the following questions in the framework:

(1) How do the students' reading, listening, and speaking skills improve, when the layered flipped learning model is used in English lessons?

(2) What are the students' opinions about the tasks chosen and performed in the layered flipped learning model?

\section{Method}

\section{Research Design}

One of the qualitative research methods, the 'action research' method was used in this research. Action research is research that helps practitioners, education managers, and teachers understand their work better (Glanz, 1999) and is a systematic process of intervention based on the fact that people do research about their professional actions and take action for change (Costello, 2007).

McKernan (1991) has collected action research into three groups as "technical-technical collaborative-scientific action research", "mutual cooperation-practice-discussion-oriented action research", "liberating -developer-critical action research". In this research, "liberatingdeveloper-critical action research type" was adopted. In this type of action research, the practitioner acquires new knowledge and experience and gains a critical perspective towards his own practices. The practitioner looks for solutions to the problems encountered in the process and tries to find rational solutions. It is aimed for the practitioner to become more proficient in his profession through research and to develop new views about his field. In this research, the English teacher as a practitioner; the practitioner took a reflective role and actively participated in the process. The research was carried out by the researcher himself and the research data was collected by the researcher himself.

\section{Study Group}

The research was conducted with the fifth grade of a secondary school in the West Black Sea region of Turkey in the 2017/2018 academic year. The class size is 18 and all students are female students. The research was carried out in a school with a suitable technological infrastructure and where students had access to technology in their homes. The researcher was assigned to this school as an English teacher in the second semester of 2017/2018 academic year.

\section{Implementation Process}

Two action plans were developed throughout the implementation. Before the first action plan was prepared, the teachers, students, and 5 English teachers working in different locations were interviewed. As a result of the interviews, information about the lesson process, materials used, assessment process, and attitudes of teachers and students towards 
English were obtained. After a literature review on foreign language teaching, the first action plan of the layered flipped learning model was prepared by considering the English language curriculum.

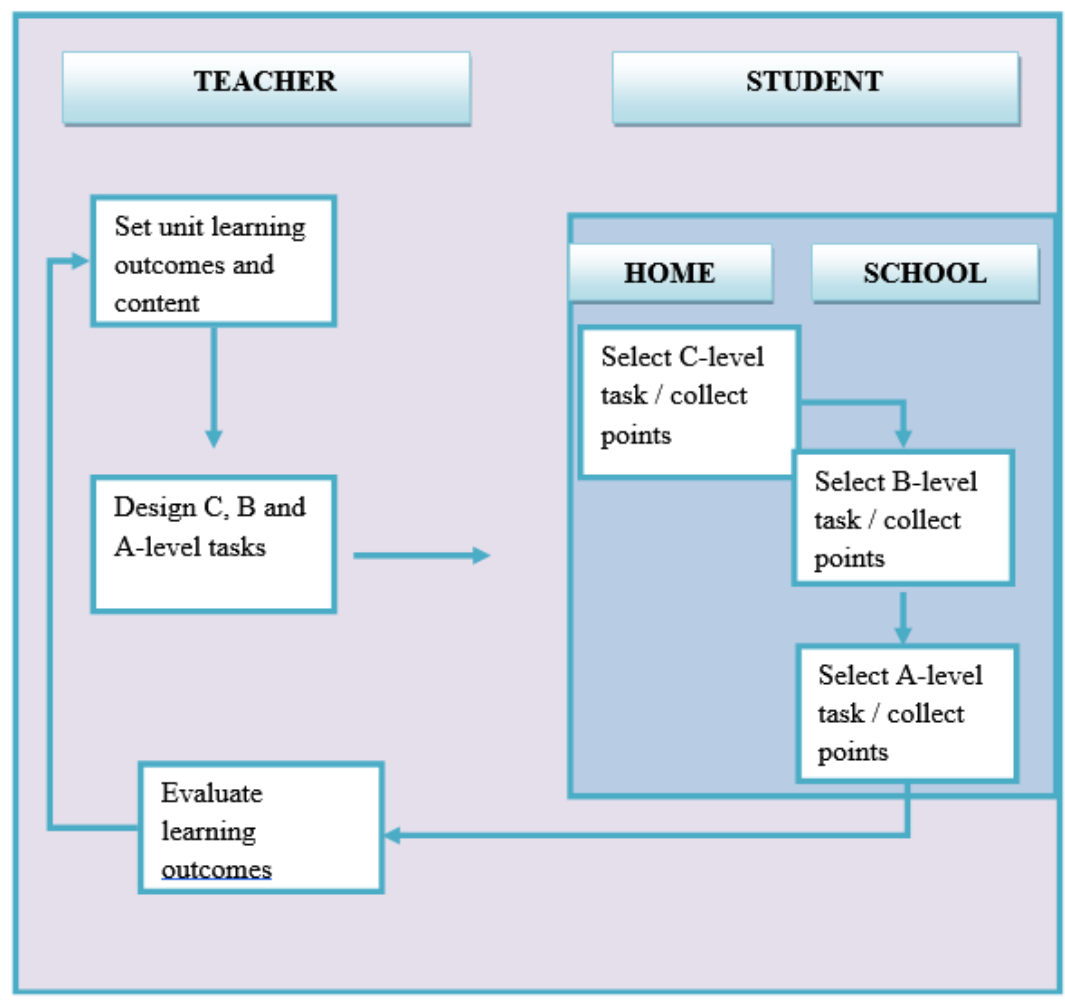

Figure 1. Layered Flipped Learning Model

The tasks sent home throughout the action plan were prepared at the $\mathrm{C}$ level. Class tasks were at levels B and A. The duties of the students in the process were as follows:

Students were first asked to complete their C-level tasks at home. The C-level tasks were designed in a way that students could acquire knowledge at a basic level, such as video lectures, word slides, online games, book tasks, worksheets, and listening activities.

After completing the C-level tasks, students started doing B-level tasks in the classroom. Students who could not complete the $\mathrm{C}$-level tasks at home were given the opportunity to complete these tasks in the classroom. These students were able to start their B-level tasks if they finished their C-level tasks in the classroom. B-level tasks were tasks that required higher skills, such as dice games, dart games, role-playing, and story creation, where students could apply what they learned in the C-level tasks.

Students who completed B-level tasks moved on to the A level, which is the last level. Students who completed the A level completed the unit. A-level tasks were the ones students developed skills and competencies such as creative thinking, working creatively with others, judgment and decision-making, and project production. These tasks included dictionary preparation, research, poster preparation, and song composition.

Students were given a list of home tasks they needed to do before the coming lesson and a list of classroom tasks they would do in the classroom. The students were asked to choose the tasks and complete them in order to obtain the score specified by the task list. The home tasks 
were sent to the students via the Education Information Network (EIN) of the Ministry of National Education and WhatsApp or by uploading them to portable memory. As the students completed their tasks, they delivered them to the teacher in the same way.

The students reported their chosen classroom tasks to the teacher via EIN or WhatsApp before beginning the lesson. In this way, the materials could be prepared in sufficient numbers and groups were formed beforehand. After the students finished a task, their tasks were evaluated according to the task's scoring instructions and the task lists were signed. After each level, a certificate of achievement was distributed to the students in order to motivate them.

The first action plan was designed to last for 4 weeks and 12 hours. However, the first action plan was completed in 5 weeks and 15 hours because the students completed their tasks one week later than planned.

During the first action plan, task evaluation forms collected from students every week, reflective diaries written by the teacher after each lesson, and video recordings were analyzed meticulously and the second action plan was prepared in line with the data obtained.

The second action plan was originally prepared to last for 4 weeks and 12 hours, covering units 7 and 8. However, according to the results obtained from the students' feedback and class observations, it was decided that the third action plan was not needed.

\section{Data Collection Tools and Data Collection}

\section{Data Collection Tools and Data Collection For The First Research Question}

Readiness Test: A multiple-choice readiness test covering the learning outcomes of the first semester was prepared to find out if there was a lack of pre-learning of the students. Firstly, a table of specifications was prepared for the first term learning outcomes and more than one question was written for each learning outcome. Opinions of three experts were taken for draft reading, listening and speaking skills tests. One of these specialists is a faculty member of the English Language Teaching Department and the other two are faculty members of the Curriculum and Instruction Department. After the experts examined the table of specifications and the draft questions, the tests were pre-applied.

The tests were applied to 62 students and the discrimination and difficulty indexes of each item were calculated. In order to accept the discrimination of the substance, it must be 0.30 and above. Substances with a discrimination of 0.40 and above are considered very good (Başol, 2013; 236). In the listening and reading skill tests, items with a discrimination index of 0.29 and below were discarded. In addition, if more than one item is left in one learning outcome, the item with the best discrimination was selected. As a result of the analyses performed with test analysis program (TAP), the average difficulty level of listening skill test was 0.6 and the reliability coefficient was KR-20 0.72; The average difficulty level of the reading skill test was 0.57 and the reliability coefficient KR-20 was 0.78 . Accordingly, readiness tests can be said to be of medium difficulty and reliable. As a result, listening skill test consisted of 17 items and reading skill test consisted of 21 items.

Achievement test: Two different multiple choice reading, listening and speaking skills tests were developed to be used at the end of the action plans. The first achievement test includes $5^{\text {th }}$ and $6^{\text {th }}$ units (first action plan); the second achievement test includes $7^{\text {th }}, 8^{\text {th }}$ and $9^{\text {th }}$ units (the second action plan). First, the table of specifications was prepared in two of the 
achievement tests. Opinions of three experts were taken for draft reading, listening and speaking skills tests. One of these specialists is a faculty member of the English Language Teaching Department and the other two are faculty members of the Curriculum and Instruction Department. After the experts examined the table of specifications and the draft questions, the tests were pre-applied. There are 10 questions in the first draft listening skill test and 25 questions in the draft reading skill test; there are 23 questions in the second draft listening skill test and 18 questions in the draft reading skill test.

First achievement test was applied to 58 and the second achievement test was applied to 56 students. The discrimination and difficulty indexes of each item were calculated. In the listening and reading skill tests, items with a discrimination index of 0.29 and below were discarded. In addition, if more than one item is left in one learning outcome, the item with the best discrimination is selected. As a result of the analyses performed with the TAP program, the average difficulty level of the first listening skill test was 0.48 and the reliability coefficient was KR-20 0.76; the mean difficulty level of the first reading skill test was 0.53 and the reliability coefficient was calculated as KR-20 0.71. The analysis results of the second success test are as follows: The mean difficulty level of the listening skill test was 0.51 and the reliability coefficient was KR-20 0.73; the average difficulty level of the reading test was 0.55 and the reliability coefficient KR-20 was 0.75 . Accordingly, both success tests can be said to be of medium difficulty and reliable tests.

Prepared speech method was chosen to measure speech skills. Because as stated in the Common European Framework for Languages, a B1 level learner can speak in a foreign language without preparation (Council of Europe, 2002). According to the English Curriculum, fifth grade students are A1 level learners in our country (MoNE, 2017). For this reason, in both evaluations one week in advance, the students were told about the topics they would speak and they were prepared. Questions were asked to the students on the given topics or they were asked to make a dialogue or talk about the subject. Speech assessment form was developed and used after obtaining expert opinions.

\section{Data Collection Tools and Data Collection For The Second Research Question}

Focus Group Interview: A focus group interview was held at the end of the semester. In the focus group interview method, people with commonalities are brought together and asked for their views and thoughts on a particular topic. Instead of individual ideas or opinions of the participants, common views and ideas are tried to be revealed (K1lıç et. al., 2019). Focus groups usually consist of 7-10 people (McCawley, 2009). In this study, focus group interviews were conducted with 10 volunteer students in an empty classroom of the school. Focus group interviews aimed to learn the students' feelings and thoughts about the application. Before the interview, the students were informed that their identities would be kept confidential and permission was asked to use a voice recorder. The interview lasted 54 minutes. No data other than voice recording has been collected or analyzed.

\section{Data Analysis}

The readiness test used before the first action plan and the achievement tests used at the end of the first and second action plans were tabulated separately to show the scores of each student, the development of each student in the process and the class averages. In addition, the changes of students and class in the process are visualized with graphics.

The data obtained from the focus group interview at the end of the action plans were analyzed 
using the content analysis method, the data obtained were coded and themed. Content analysis combines similar data into specific concepts and themes, transforming them into a format that the reader can understand and interpret (Fraenkel \& Wallen, 2000). In this study, coding, classification and interpretation steps which are the stages of content analysis (Kıliç et. al., 2019) were followed. One of the coding types; "coding based data" was chosen and all codes were developed in the analysis process without predetermined codes. Then, themes were created by looking at the characteristics of the data. The relationships and differences between the themes developed through classification were determined. In the first stage, several and temporary themes were identified. Themes that have a similar meaning and can be merged into higher themes have been identified and tried to reach clearer results. Finally, the data obtained were interpreted and explained. Students were coded as S1, S2, S3 ... and quotations from the students' discourses were made using their original expressions.

\section{Validity and Reliability}

The data collected within the scope of the research were coded twice with the code recode strategy. This strategy requires the researcher to encode the same data twice, giving at least one or two weeks of waiting time between each encoding. The two encoding results are compared to see if the results are the same or different (Anney, 2014). Within the scope of this research, the focus group interview was re-coded by the researcher and consistency was calculated. Consistency was calculated by using the reliability formula proposed by Miles and Huberman (1994), "Reliability = Consensus / (Consensus + Disagreement)". The agreement between the codings was found to be $91 \%$. Studies with a coefficient of agreement above $70 \%$ are considered reliable (Miles \& Huberman, 1994). This result shows that the research is reliable.

\section{Findings}

\section{Findings on The First Research Question}

\section{Reading Skills Achievement Test Results}

The readiness achievement tests used before the first action plan and the readiness achievement tests used at the end of the first and second action plans are presented in Table 1 , showing the success of each student out of 100.

Table 1. Reading Skills Achievement Test Results

\begin{tabular}{llll}
\hline & Readiness Achievement Tests & 1.Achievement Tests & 2.Achievement Tests \\
\hline S1 & 42.85 & 75 & 87.5 \\
\hline S2 & 38.09 & 50 & 62.5 \\
\hline S3 & 80.95 & 100 & 100 \\
\hline S4 & 38.09 & 62.5 & 75 \\
\hline S5 & 61.90 & 62.5 & 87.5 \\
\hline S6 & 57.14 & 75 & 87.5 \\
\hline S7 & 85.71 & 100 & 100 \\
\hline S8 & 38.09 & 50 & 62.5 \\
\hline S9 & 57.14 & 75 & 100 \\
\hline S10 & 47.61 & 50 & 62.5 \\
\hline S11 & 57.14 & 75 & 100 \\
\hline S12 & 66.66 & 75 & 87.5 \\
\hline S13 & 57.14 & 87.5 & 87.5 \\
\hline S14 & 76.19 & 75 & \\
\hline
\end{tabular}




\begin{tabular}{llll}
\hline S15 & 57.14 & 75 & 100 \\
\hline S16 & 61.90 & 75 & 75 \\
\hline S17 & 57.14 & 62.5 & 87.5 \\
\hline S18 & 42.85 & 50 & 75 \\
\hline Mean & 56.87 & 70.83 & 84.72 \\
\hline
\end{tabular}

As shown in Table 1, the readiness test results of the students are lower than the achievement test results. This situation was also influenced by the inability of students to obtain the learning outcomes of the fifth unit included in the readiness test on time. All of the students were more successful in the $1^{\text {st }}$ achievement test than the readiness test; they were more successful in the $2^{\text {nd }}$ success test than the $1^{\text {st }}$ success test.

According to the readiness and achievement tests applied during the semester, the variation of class averages during the period was shown in Figure 2.

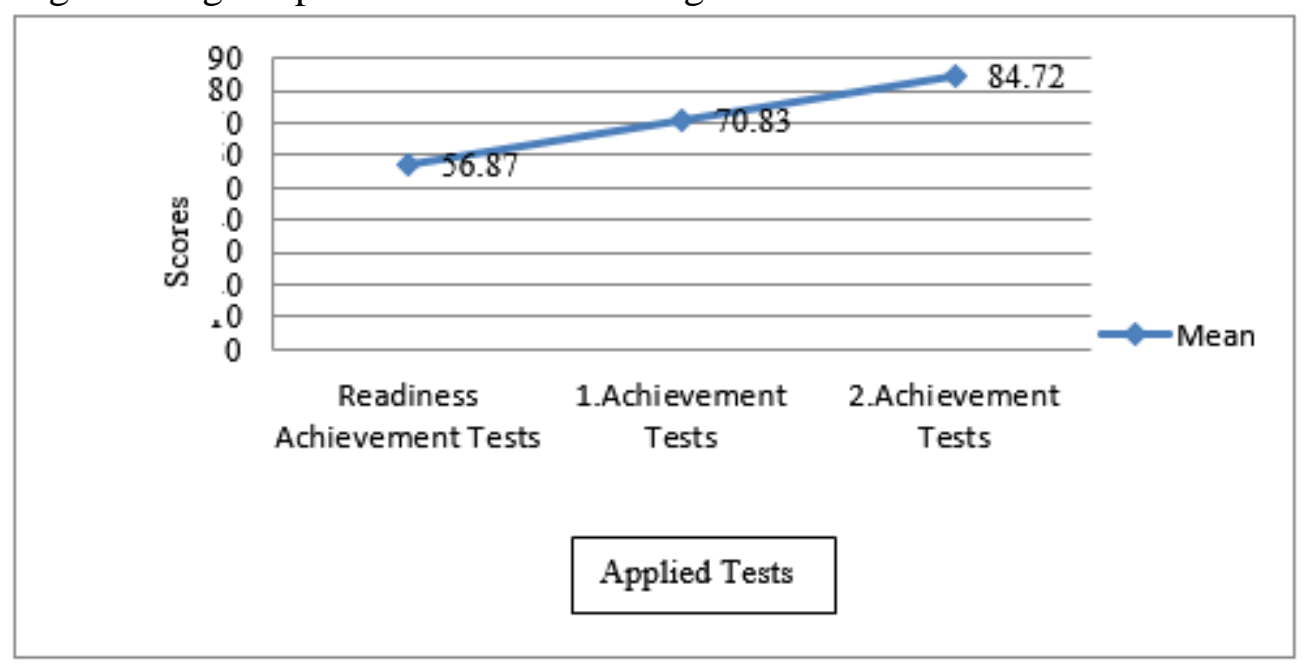

Figure 2. Reading Skill Class Average

As shown in Figure 2, the average readiness test of the class is 56.87; the first achievement test average was 70.83; the second success test average was found to be 84.72 . The increase in the class average during the semester indicates that there has been a significant improvement in students' efforts and course success. As a result of the second action plan, the data gathered to measure the achievement of reading skills shows that the achievement of reading skills of the students is quite good.

\section{Listening Skills Achievement Test Results}

The readiness achievement tests used before the first action plan and the readiness achievement tests used at the end of the first and second action plans are presented in Table 2, showing the success of each student out of 100 .

Table 2. Listening Skills Achievement Test Results

\begin{tabular}{llll}
\hline & Readiness Achievement Tests & 1.Achievement Tests & 2.Achievement Tests \\
\hline S1 & 58.82 & 80 & 100 \\
\hline S2 & 70.58 & 80 & 87.5 \\
\hline S3 & 58.82 & 60 & 62.5 \\
\hline S4 & 29.41 & 40 & 62.5 \\
\hline S5 & 35.29 & 40 & 62.5 \\
\hline S6 & 64.70 & 60 & 75 \\
\hline
\end{tabular}




\begin{tabular}{llll}
\hline S7 & 58.82 & 60 & 87.5 \\
\hline S8 & 64.70 & 80 & 100 \\
\hline S9 & 64.70 & 80 & 100 \\
\hline S10 & 47.05 & 60 & 75 \\
\hline S11 & 64.70 & 80 & 87.5 \\
\hline S12 & 58.82 & 60 & 87.5 \\
\hline S13 & 29.41 & 40 & 62.5 \\
\hline S14 & 76.47 & 100 & 100 \\
\hline S15 & 64.70 & 80 & 100 \\
\hline S16 & 64.70 & 80 & 87.5 \\
\hline S17 & 70.58 & 80 & 100 \\
\hline S18 & 47.05 & 60 & 75 \\
\hline Mean & 57.18 & 67.77 & 84.02 \\
\hline
\end{tabular}

As shown in Table 2, the readiness test results of the students are lower than the achievement test results. This situation was also influenced by the inability of students to obtain the learning outcomes of the $5^{\text {th }}$ unit included in the readiness test on time. All of the students were more successful in the $1^{\text {st }}$ achievement test than the readiness test; they were more successful in the $2^{\text {nd }}$ success test than $1^{\text {st }}$ success test.

According to the readiness and achievement tests applied during the semester, the variation of class averages during the period was shown in Figure 3.

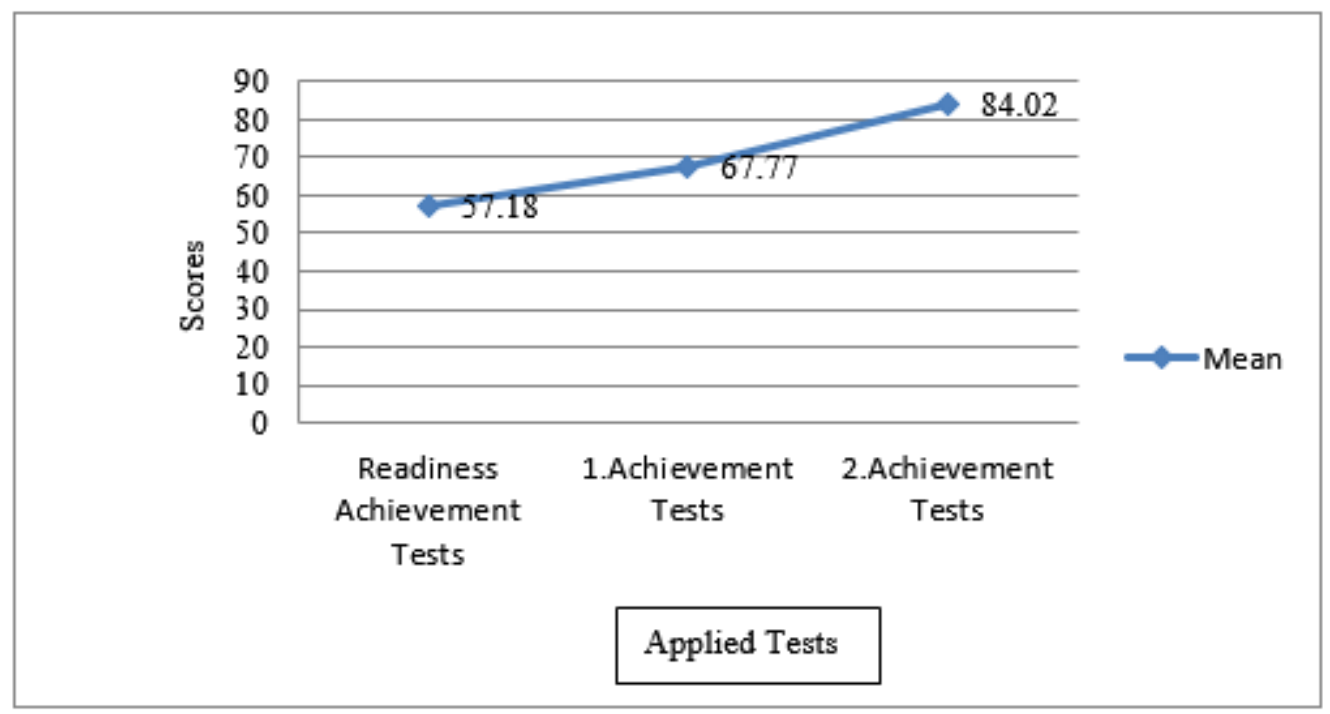

Figure 3. Listening Skill Class Average

As shown in Figure 3, the average readiness test of the class is 57.18; the first achievement test average was 67.77; the second success test average was found to be 84.02 . The increase in the class average during the semester indicates that there has been a significant improvement in students' efforts and course success. As a result of the second action plan, the data gathered to measure the achievement of listening skills shows that the achievement of listening skills of the students is quite good.

\section{Speaking Skills Achievement Test Results}

The readiness achievement tests used before the first action plan and the readiness achievement tests used at the end of the first and second action plans are presented in Table 3, showing the success of each student out of 100. 
Table 3. Speaking Skills Achievement Test Results

\begin{tabular}{llll}
\hline & Readiness Achievement Tests & 1.Achievement Tests & 2.Achievement Tests \\
\hline S1 & 69 & 87 & 90 \\
\hline S2 & 79 & 82 & 88 \\
\hline S3 & $\mathbf{5 9}$ & 76 & 82 \\
\hline S4 & $\mathbf{5 4}$ & 71 & 84 \\
\hline S5 & $\mathbf{4 2}$ & $\mathbf{5 5}$ & 88 \\
\hline S6 & $\mathbf{5 9}$ & 76 & 92 \\
\hline S7 & 73 & 80 & 87 \\
\hline S8 & 77 & 79 & 79 \\
\hline S9 & $\mathbf{5 7}$ & $\mathbf{6 0}$ & 92 \\
\hline S10 & 69 & 90 & 87 \\
\hline S11 & 71 & 74 & 90 \\
\hline S12 & $\mathbf{5 3}$ & 72 & 92 \\
\hline S13 & 77 & 90 & 92 \\
\hline S14 & 79 & 90 & 86 \\
\hline S15 & 72 & 76 & 94 \\
\hline S16 & $\mathbf{5 2}$ & 76 & 79 \\
\hline S17 & 70 & 84 & 87.5 \\
\hline S18 & $\mathbf{4 2}$ & $\mathbf{5 2}$ & \\
\hline Mean & 64.11 & 76.11 & \\
\hline
\end{tabular}

The speech assessment form, which is used to measure students' speaking skills, evaluates the way students communicate in three stages. These are communicating with words, communicating with phrases, and communicating with sentences. As a result of the readiness test, it was observed that there were no students who communicated with words, but instead of establishing sentences, S3, S4, S5, S6, S9, S12, S16 and S18 communicated with phrases. These students are shown in bold in Table 3. As a result of the first achievement test, it was seen that students who communicated phrases decreased and only S5, S9 and S18 communicated with phrases instead of forming full sentences. As a result of the second achievement test, it was seen that there were no students who communicated with phrases, and all of the students communicated by forming sentences.

As shown in Table 3, the readiness test results of the students are lower than the achievement test results. This situation was also influenced by the inability of students to obtain the learning outcomes of the fifth unit included in the readiness test on time. All of the students were more successful in the $1^{\text {st }}$ achievement test than the readiness test; they were more successful in the $2^{\text {nd }}$ success test than the $1^{\text {st }}$ success test.

According to the readiness and achievement tests applied during the semester, the variation of class averages during the period was shown in Figure 4. 


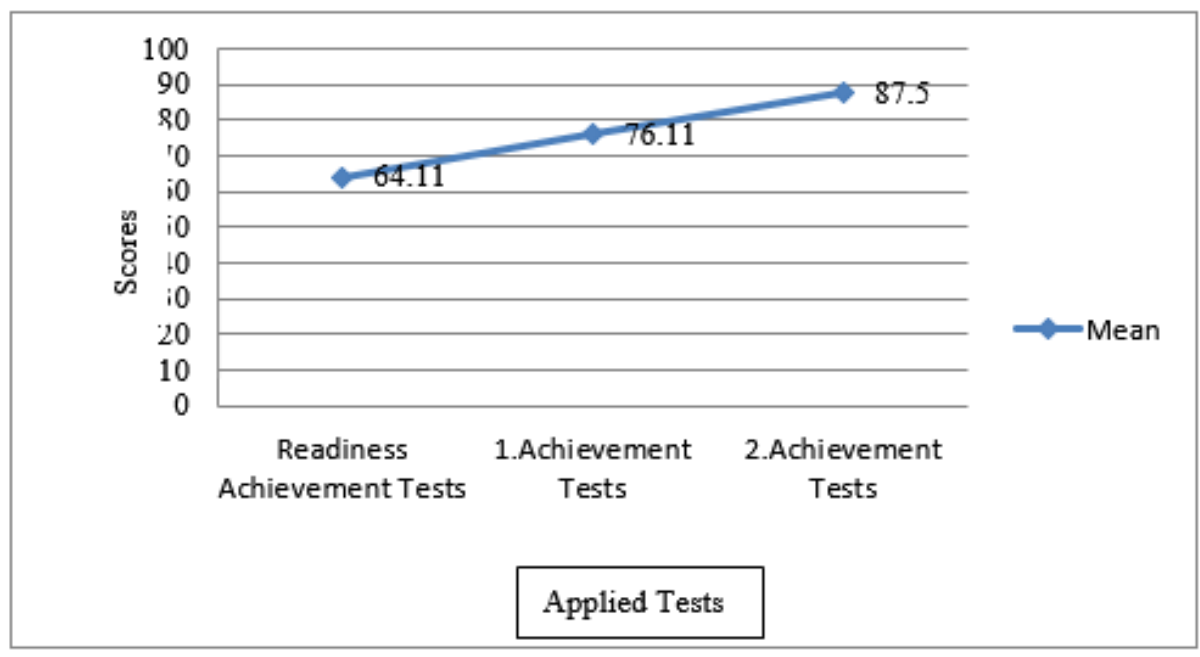

Figure 4. Speaking Skill Class Average

As shown in Figure 4, the average readiness test of the class is 64.11; the first achievement test average was 76.11 ; the second success test average was found to be 87.5 . The increase in the class average during the semester indicates that there has been a significant improvement in students' efforts and course success. As a result of the second action plan, the data gathered to measure the achievement of speaking skills shows that the achievement of speaking skills of the students is quite good.

\section{Findings on The Second Research Question}

\section{Opinions about Class Tasks}

At the end of the second action plan, students' opinions about class tasks are presented in Table 4 under the themes.

Table 4. Opinions About Class Tasks

\begin{tabular}{ll}
\hline Themes & Codes \\
\hline Motivation & It's fun \\
& I'm not bored \\
& Love the course so much \\
& I feel sorry when I can't come to class \\
\hline Educational & I can make sentences \\
& I learn better / easier \\
& I understand better through games \\
& I can answer questions \\
& I consolidate the subject with the activities \\
& I think I've improved myself \\
& I think my English is improving \\
& I think I learned the most this semester. \\
& I find it hard \\
Love it so much \\
I understand better \\
I consolidate words \\
I make better dialogue now \\
I think it is educational \\
I think it's fun \\
I think I can learn English \\
My English does not improve at all if I don't make dialogue
\end{tabular}


As seen in Table 4, opinions about class tasks consist of themes of "motivation", "educational" and "establish dialogue".

The students stated that they were not bored, they liked and enjoyed the tasks. One of the students S6 who participated in the focus group interview expressed his thoughts on this subject as follows: "I didn't think time would be so much fun in class. We had a lot of fun in the second semester thanks to you." S14 stated that she would like to participate in class tasks as follows: "I was a little sick last weekend. I was so sorry I couldn't come. God helped me, I came to be healed." S2 expressed her thoughts about class tasks as "I think all the tasks were fun. I loved them all. I hope so next year."

The students found their classroom tasks as educational in general and stated that they learned how to make sentences and answer questions, consolidate the subject with activities and improve their English. The students participating in the focus group interview stated that classroom tasks were educational as follows: S15:"I think we wouldn't have learned if class tasks weren't like . It's both fun and you can learn the unit." S9: "Thanks to these tasks, I can now make better sentences. My English has improved." S2: "You learn about the subject at home. And you consolidate them in class. So what you've learned is permanent."

Class tasks include tasks that require students to a establish dialogue to improve their speaking skills. The students stated that although it was difficult to establish a dialogue, they learned better, consolidate words and improved their English. S14 expressed her thoughts about establishing dialogue as "At first, I had more difficulty in dialogue. It's better now. I can say everything I learned thanks to dialogues." S17: "I love it very much. I think my English was better. Now I understand things better." S12: "It seems that you can learn better in this way. Now I try to talk to myself at home."

\section{Opinions about Home Tasks}

At the end of the second action plan, the opinions of the students about their home tasks are presented in Table 5 under the themes.

Table 5. Opinions About Home Tasks

\begin{tabular}{ll}
\hline Themes & Codes \\
\hline Lecture videos & I can watch it again \\
It's fun & I learn faster \\
It is useful in writing \\
I'm learning how to make sentences \\
I learn words and subjects better \\
It makes class tasks easier \\
I love watching teacher videos more \\
\hline I understand the subject faster \\
I use it for dialogue \\
I can learn faster when it was illustrated \\
It makes easy for me to understand reading texts \\
It makes class tasks easier \\
\hline It's fun \\
I can do it without difficulty \\
It allows me to learn the subject and the words \\
It allows me to complete class tasks on time \\
I think it's easier than class tasks \\
\hline
\end{tabular}

As seen in Table 5, opinions about home tasks consist of themes of "lecture videos", "word 
slides" and "other tasks".

The students stated that lecture videos enable them to learn subjects better, make it easier to do class tasks, teach establishing sentences, prefer teacher videos and they find the videos fun. S3 expressed her thoughts about lecture videos as "Thanks to these videos I have learned at home thoroughly. Taking notes. It's good." S8: "If I came without watching the videos, I'd be left behind in class assignments. I'm learning there so I'm making it easier in the classroom." S9: "Sir, we are watching your videos with my brother. He also studies with your videos. We learn to make sentences." S14 stated that they liked teacher videos rather than ready-made narration videos as follows: "Sir, the videos you have are more beautiful. I'm listening to them. I don't like the other woman." S15 stated that they learned better because they could watch the lecture videos as much as they wanted and when they want as follows: "I fell asleep watching unit 8 video. It repeated it so much until morning. When I got up in the morning, everything you said was in my head. I never forget." S17: "Since we can watch the video over and over again, we can learn better. And I refer to it before the exam. It's good."

The students stated that they learned the subject better by means of word slides, and that the word slides facilitated establishing dialogues and understanding of reading texts. S12 expressed her thoughts about it as "I take notes of the words there. Then I use it when I make dialogues in the classroom. It was comfortable." S2: "I do it first. Then I watch the video. It makes understanding the subject easier."

It was seen that students think other classroom tasks are educational, such as lecture videos and word slides, they make it easier for students to do their class tasks and they are fun. Students expressed their thoughts about other tasks as follows: S6 "I'm not having any trouble. You know you're sending a link. When I make them, I learn words or something. I think the games are fun too." S3 "I do my home tasks on time. So I learn subjects and words better. I do it without getting bored." Home tasks are prepared at a lower level than class tasks and as a basis for class tasks. S14 expressed this as follows: "Class tasks are easier when you do your home tasks. That's why I'm not coming without doing them. And they're easier."

\section{Opinions about the Use of EIN}

At the end of the second action plan, the opinions of the students about the usage of EIN are presented in Table 6 under the themes.

Table 6. Opinions About the Usage of EIN

\begin{tabular}{ll}
\hline Themes & Codes \\
\hline Positive & I like EIN Foreign Language Portal \\
& It's fun \\
& I'm learning new words \\
& I send tasks easy \\
& I learn words from games \\
& I feel cool because I use social media \\
& I can easily reach my teachers and friends from chat \\
\hline Negative & I have trouble in logging in \\
& I find the videos in EIN are boring \\
& I have difficulty sending tasks \\
& I can't use it because website doesn't load \\
\hline
\end{tabular}

Some of the students have positive opinions about the usage of EIN while others have negative opinions. Students with positive views expressed that the EIN was fun, allowed them to learn words and made communication easy. 
Students expressed their thoughts about the usage of EIN as follows: S9 "The games are fun and I learn words thanks to them. That's why I choose those tasks." S15 "I'm talking to those who access the EIN. When I have difficulty in something, somebody answers even if it's not you. It's good."

Students who have negative opinions about the usage of EIN stated that they did not like this application because of the difficulties they had in accessing and using the EIN rather than the content of EIN. Students expressed their thoughts about it as follows: S2 "I'm getting mad at the EIN. It never loads. If it loads, then it is too slow. It's a good thing we were able to do the tasks without sending it from there." S8 "How long did I wait at first? Oh my God! Sending tasks takes a lot of time."

\section{Opinions about the Usage of WhatsApp}

At the end of the second action plan, the opinions of the students about the usage of WhatsApp are presented in Table 8 under the themes.

Table 7. Opinions About the Usage of WhatsApp

\section{Codes}

I can reach the teacher more easily

My family can follow my homework

I can send my tasks more easily

I can make listening tasks more comfortable

I feel important because I'm in the same group with the teacher

I can listen to lecture videos anytime and anywhere

The students were generally pleased to use WhatsApp during the semester. They stated that in this way, they reached the teacher more comfortably, they sent tasks more comfortably, completing listening tasks was more comfortable and watching the lecture videos was more comfortable. The students expressed their thoughts about WhatsApp's being more comfortable to use as follows: S3: "It is more comfortable because you send listening texts there. I listen whenever I want and as much as I want. Both texts are easier to open from there." S17: "From there, tasks are sent more easily. It is easy to access. Accessing the EIN is a big problem."

\section{Opinions about Group Work}

At the end of the second action plan, students' opinions about group work are presented in Table 8 .

Table 8. Opinions About Group Work

\begin{tabular}{ll}
\hline Themes & Codes \\
\hline Positive & Lessons are fun \\
& I finish my tasks sooner \\
& We learn to respect each other \\
& It is easier when the task is distributed \\
& I learn better because we help each other. \\
& We teach each other what we don't know \\
& I learn words by working with my friends \\
& I feel happy to spend time with my friends \\
\hline Negative & There can be fighting \\
& Sometimes I disagree \\
& It's easier when there's no band \\
& There is a lot of indecision in the choice of task
\end{tabular}


Completing task takes longer in group of 4

We're having trouble when our ideas don't match.

I have to wait because of my friend

I get angry when my group friends don't fulfill their responsibilities

Although there were individual tasks in class tasks, students preferred to work in groups more during the term. However, although they preferred to be engaged in group work, it is seen that the students have both positive and negative opinions about the group work. This shows that even if there are some problems during group work, the contribution of group work to student learning is not hindered.

Students who have positive opinions about group work stated that group work is educational and fun. S2 stated that group works are educational as follows: "Sir, lessons are always more fun when we are together. For example I don't know, and he does. We're telling what to do to each other. We learn more easily." Another student expressed their thoughts about group work as follows: S15: "Tasks end earlier in this way. We work together. So we help each other. It is for sure that two heads are better than one." S9: "I think we learn better and we learn to respect each other. Because we have to wait at that time or something."

The students who have negative opinions about the group work stated that they experienced problems during the group work, they could not sometimes agree and they had to wait. S14 explained the difficulties she experienced during the group work as follows: "I was working with someone a few weeks ago. We couldn't decide on tasks. We always chose what she wanted. Anyway, she always criticized my sentences. I got angry with her." S8 stated her opinions about this as follows: "It's good to work with friends, but not always. Sometimes you fight. I mean, wait, wait, and you get nervous when she doesn't do anything."

\section{Discussion, Conclusion and Implications}

\section{First Research Question}

Layered flipped learning model has a positive effect on students' academic achievement. In the literature, there are studies indicating that flipped learning increases students' academic achievement (Bishop \& Verleger, 2013; Butt, 2014; Mason, Shuman \& Cook, 2013).

It was observed that students' academic success gradually increased in all of their reading, listening and speaking skills. It was seen that the success of students in reading skills increased from $56 \%$ at the beginning of the semester to $70 \%$ in the first exam and $84 \%$ in the second exam. As a result of the study that it was done in order to determine the effect of flipped learning model on students' academic reading skills, Brown (2018) stated that this model was effective in developing reading skills and strategies. Likewise, Degenhart and Bond (1981) tried this method in a secondary school in which French was taught as a foreign language and stated that the method was effective in acquiring reading skills. These results are consistent with the results of this study. Reading comprehension is the process of making sense and structuring by providing participation and interaction in a text (Snow, 2002). It is thought that because reading activities are designed to enable students to work on the text and make comments, rather than just reading the text in layered flipped learning model and increasing the opportunity of students to practice in the classroom this model is effective in the development of students' reading skills. 
It was seen that the success of the students in listening skills increased from $57 \%$ at the beginning of the semester to $67 \%$ in the first exam and $84 \%$ in the second exam. Ahmad (2016) conducted an experimental research in order to determine the effect of the flipped learning model on listening skills and concluded that the model had a significant effect on listening skills. Likewise, Amiryousefi (2019) stated that the model has a positive effect on listening skills as a result of his study to determine the effect of the flipped learning model on listening skills. These results are consistent with the results of this study. Within the scope of the layered flipped learning model, students completed simple activities according to the listening texts at home. In the classroom, they were given the opportunity to complete the activities that enabled them to immediately understand and respond to what they listened to through dialogue or speeches. It is thought that activities at different levels, increasing the opportunity of students to practice in the classroom and active participation of all students are effective in increasing student achievements.

It was seen that the academic success of the students in speaking skills increased from $64 \%$ at the beginning of the semester to $76 \%$ in the first exam and $87 \%$ in the second exam. Bademci and Özkan (2019) applied the flipped learning model at the fifth grade level and investigated the effect of this model on students' speaking skills. According to the results of this study, the success rate of speech test increased from 67\% to 87\%. Likewise, Amiryousefi (2019) concluded that this model increases students' speaking skills. Degenhart and Bond (1981) also applied this method in a secondary school in which French was taught as a foreign language and concluded that the method had a positive effect on speaking skills. These results are consistent with the results of this study. Within the scope of the layered flipped learning model, students were assigned tasks like preparing a dialogue or a speech in the classroom after learning the sentence structures and were involved in ways of making dialogues through activities at home. Increasing the opportunity of students to practice in the classroom and ensuring the active participation of all students in the process are thought to be effective in increasing student achievements.

\section{Second Research Question}

It was seen that layered flipped learning model learning model does not require major changes in the physical structure of schools and it is sufficient to have a few computers available to students in schools. However this situation does not match with Öztürk's (2016) study. In his study, Öztürk (2016) stated that the flipped learning model can be applied in schools and students with good information technologies infrastructure and internet access.

Class tasks were found to enable students to learn better and improve themselves. In addition to this, it was concluded that providing students with task options to keep the students active, to be able to practice and to attract students' interest in the layered flipped learning model enable the students to find their class tasks fun and educational. Turan and Göktaş (2015) applied this method in order to determine students' views on the flipped learning model and concluded that students think that this model is a fun and flexible model that improves the permanence of learning, facilitates learning. Likewise, Sirakaya (2017) tried to determine the students' opinions about this model and concluded that the students defined this model as a model that enabled them to participate actively, that they learned with fun and increased their interaction and motivation. Because providing students with various activities increases their motivation and active participation. In this case it has a positive effect on student learning (Grandgenett, Harris \& Hofer, 2010: 26). 
It was concluded that organizing activities that require establishing dialogues contributed to the development of students' speaking and listening skills and made them consolidate the newly learned vocabulary. Particularly activities such as role playing are very important for gaining communication skills such as speaking, listening and watching (Maden, 2010: 516517). In order to prevent the problem of students not being able to speak in real environments, role-playing practices related to dialogues should be included during the learning process. The sentence structures intended to be taught through dialogue should be well planned. This technique should be used effectively in the classroom especially in order to improve speaking and listening skills. In the literature, there are studies that conclude that drama activities increase students' speaking skills (Aykaç \& Çetinkaya, 2013).

It was seen that videos in which the teacher herself appeared more preferred and the illustrated and colored word slides were more effective. In addition, it was concluded that the preparatory nature of the home tasks to the class tasks made it easier for the students to do the class tasks, to learn words and make sentences, and that the home tasks were useful before exams. In the literature, there are studies indicating that the studies conducted at home in the flipped learning model are disadvantageous for this model (Sirakaya, 2017; Turan \& Göktaş, 2015), and there are also studies indicating that the studies conducted at home increase the active participation and success of the students (Arslan \& Kuzu, 2019; Talbert, 2012). The fact that this study was carried out with the action research method and changes made according to the needs and opinions of the students in the process may have provided the students' views on this subject to be positive.

It was concluded that EIN can be used in the teaching process if the hardware problems are solved and the infrastructure is improved but there are some problems in the current situation. In their study, Arslan and Kuzu (2019) concluded that EIN can be used in the classroom where the flipped learning model is applied. Arslan and Kuzu (2019) reached both positive and negative opinions about the usage of EIN in their study. They stated that although EIN increases student academic success and interest, internet connection problems, computer problems, students' inability to use it effectively and hardware problems make it difficult to resort to it in the flipped learning model. These results are consistent with the results of this study.

In the case where the layered flipped learning model is applied, it was seen that alternative technological applications should be presented to the students. It was concluded that a simple application such as WhatsApp could be used in this model, it facilitated the process and was gladly used by the students. Fattah (2015) and Manan (2017) also concluded that using WhatsApp outside the classroom makes students happy, help them feel more comfortable and provides an opportunity to learn in a comfortable environment. These results are consistent with the results of this study. The fact that communication with WhatsApp is faster and easier, and that in this application listening activities can be done and videos and slides can be watched might have encouraged students to use this application.

It was concluded that group work was effective in the learning of students and that the lessons were fun. The flipped learning model is a model that allows students to do more collaborative work and practice (Abeysekera \& Dawson, 2014). Opportunities for cooperative learning and group work were created for students in the classroom environment in the layered flipped learning model. Cooperative learning is an approach aimed at improving students' cognitive processes, increasing their learning achievement and improving their low learning outcomes. In the literature, there are studies showing that cooperative learning positively affects student 
achievement (Astra, Wahyuni \& Nasbey, 2015) and attitudes (Özdoğan, 2008) towards learning. It was considered that because cooperative learning provides positive faithfulness among students, provides face-to-face supportive communication opportunities, develops social skills and gives individual responsibility on students, in this application, students continue to choose group work.

It was seen that interactions in group work helped students to support each other, to help each other to learn, to develop friendship relations and empathy feelings. Group work is based on the creation of new contexts by peers in a socio-cultural context reflecting their own social environments in interaction (Aktay \& Gültekin, 2015). Group work in other words cooperative learning helps to develop learning environments for students concentrating on team work skills, emotional and psychological health, self-confidence, problem solving, empathy, positive interpersonal social relationships (Ning, 2013). Group members support each other by helping, guiding, encouraging each other.

During the group work, problems such as disagreement/conflicts, friendship issues and waiting for too long for friends weredetermined . Likewise Gelici and Bilgin (2011) also examined students' views on cooperative learning techniques and concluded that in addition to the positive opinions, the students stated that they could not agree with the group members, that the group members did not fulfill their responsibilities and that they were disturbed by the noise in the classroom.Also, as a result of using cooperative learning method, Bilgin (2004), stated that some students were uncomfortable with getting the same grade with lowachievement students.

Based on the results reached at the end of the research, the following suggestions were developed:

- Activities in the teaching process should be leveled and each level should be complementary with each other.

- Classroom tasks should be prepared so that students can practice what they learn and work collaboratively.

- In order to improve the speaking and listening skills of the students, activities such as role playing and educational play should be included in the teaching process.

- Activities should be prepared to keep students active, to enable practice, and to attract students.

- Group work should be included in the teaching process.

\section{Note}

This study was produced from the first author's Ph. D. thesis named "Developing The Instructional Process In Layered Flipped Learning Model"

\section{References}

Abeysekera, L., \& Dawson, P. (2014). Motivation and cognitive load in the flipped classroom: definition, rationale and a call for research. Higher Education Research \& Development, 34(1), 1-14.

Ahmad, S. Z. (2016). The flipped classroom model to develop egyptian efl students' listening comprehension. English Language Teaching, 9(9), 166-178. 
Akgüzel, G. (2006). Illköğretim 4-8. sinıflarda yabancı dil öğretimindeki başarısızlık nedenlerinin incelenmesi [Examining the reasons for failure in teaching foreign languages in 4- ${ }^{\text {th }}$ grades]. (Unpublished master's thesis). Çukurova University Institute of Social Sciences, Adana.

Aktay, E. G., \& Gültekin, M. (2015). Peer collaboration and early reading and writing teaching. Trakya University Journal of Social Sciences, 17(1), 291-309.

Amiryousefi, M. (2019). The incorporation of flipped learning into conventional classes to enhance EFL learners' L2 speaking, L2 listening, and engagement. Innovation in Language Learning and Teaching, 13(2), 147-161.

Anney, V. N. (2014). Ensuring the quality of the findings of qualitative research: looking at trustwothiness criteria. Journal of Emerging Trends in Educational Research and Policy Studies, 5(2), 272-281.

Arslan, H., \& Kuzu, A. (2019). Teachers' opinions of applicability of EBA class module and vclass software on flipped classroom model. Bolu Abant İzzet Baysal University Journal of Education Faculty, 19(1), 20-36.

Astra, I., Wahyuni, C., \& Nasbey, H. (2015). Improvement of learning process and learning outcomes in Physics learning by using collaborative learning model of group investigation at high school. Journal of Education and Practice, 6(11), 75-79.

Aykaç, M., \& Çetinkaya, G. (2013). The effect of creative drama activities on preservice Turkish language teachers' speaking skills. Electronic Turkish Studies, 8(9), 671-682.

Başol, G. (2013). Ĕ̈itimde ölçme ve değerlendirme [Measurement and evaluation in education] ( $2^{\text {nd }}$ Edt.). Ankara: Pegem Akademi.

Bademci, T., \& Özkan, M. B. (2019). Implementation of flipped classroom in English class of 5th grade in secondary school. International Journal of Eurasian Education And Culture, 4(6), 38-50.

Baker, J. W. (2000, June). The 'classroom flip': Using web course management tools to become the guide by the side. Paper presented at 11th International Conference on College Teaching and Learning, Jacksonville, Florida, United States.

Berrett, D. (2012). How 'flipping' the classroom can improve the traditional lecture. The Education Digest, September, 37-41.

Bergmann, J., \& Sams, A. (2012), Flip your classroom: Reach every student in every class every day. Washington: International Society for Technology in Education.

Bergmann, J., \& Sams, A. (2014). Flipping for mastery. Educational Leadership, 71(4), 2429.

Bilgin, T. (2004). The use of student teams' success sections technique in elementary school seventh grade mathematics (on polygons) and application results. Uludağ University Eğitim Fakültesi Dergisi, 17(1), 19-28.

Bishop, J. L., \& Verleger, M. A. (2013, June). The flipped classroom: A survey of the research. Paper presented at $120^{\text {th }}$ ASEE Annual Conference and Exposition, Atlanta, GA.

Brown C.J. (2018) flipping the ESL/EFL academic reading classroom: a group leader discussion activity. In Mehring J. \& Leis A. (Eds.), Innovations in Flipping the Language Classroom. Springer, Singapore

Butt, A. (2014). Student views on the use of a flipped classroom approach: evidence from Australia. Business Education ve Accreditation, 6(1),33-43.

Costello, P.J.M. (2007). Action research. Continuum Books: London.

Council of Europe (2002). Common European Framework of Reference for Languages: Learning, teaching, assessment language examining and test development. Strasbourg, Council of Europe. 
Danişman, Ş., Hasırcı Eriş, H. M., Kırcaburun, K., Boyacı, Z., Şahin, Ş., Ökmen, B., \& Kilıç, A. (2017). Investigation of flipped learning approach according to expert opinions. Journal of Education and Practice, 8(26), 81-90.

Degenhart, R. E., \& Bond, C. (1981). FLIP: French language intensive program. Studies in Language Learning, 3(2), 21-30.

Enfield, J. (2013). Looking at the impact of the flipped classroom model of instruction on undergraduate multimedia students at CSUN. Techtrends: Linking Research \& Practice to Improve Learning, 57(6), 14-27.

Fattah, S. F. (2015). The effectiveness of using whatsapp messenger as one of mobile learning techniques to develop students' writing skills. Mobile Learning Techniques to Develop Students' Writing Skills, 115- 127.

Gelici, Ö., \& Bilgin, İ. (2011). Introducing cooperative techniques and examining students' opinions. Adlyaman University Journal of Science, 1(1), 40-70.

Glanz, J. (1999). A primer on antian research for the school administratars. The Clearing House, p:301 -304.

Grandgenett, N., Harris, J., \& Hofer, M. (2010). An activity-based approach to technology integration in the Mathematics classroom. NCSM Journal, 11, 19-28.

Hamdan, N., McKnight, P., McKnight, K., \& Arfstrom, K. M. (2013). The flipped learning model: A white paper based on the literature review titled a review of flipped learning. Arlington, VA: Flipped Learning Network.

Johnson, G. B. (2013). Student perceptions of the flipped classroom. (Unpublished master's thesis). The University Of British Columbia.

Johnson, L., Adams Becker, S., Estrada, V., \& Freeman, A. (2014). NMC Horizon Report: 2014 Higher Education Edition. Austin, Texas: The New Media Consortium.

Kılıç, A., Aydın, M., Ökmen, B., \& Şahin, Ş. (2019). Kuramdan uygulamaya ihtiyaç belirleme [Determining the needs from theory to practice]. Pegem Akademi.

Liu, Z., Wei, L., \& Gao, X. (2016). A study on self-regulated micro-course learning and implicitly layered flipped classroom. Theory and Practice in Language Studies, 6(4), 870-877.

Maden, S. (2010). The necessity of drama in teaching Turkish. Journal of Turkology Research, (27), 503-519.

Manan, N. A. (2017). Whatsapp mobile tool in second language learning. Indonesan EFL Journal, 3(1), 87-92.

Mason, G., Shuman, T. R., \& Cook, K. E. (2013). Inverting (Flipping) Classrooms Advantages and Challenges. Paper presented at 120th ASEE Annual Conference and Exhibition. Atlanta: ASEE.

McCawley, P. F. (2009). Methods for conducting an educational needs assessment. Idaho: University of IdahoExtension.

McCallum, S., Schultz, J., Sellke, K., \& Spartz, J. (2015). An examination of the flipped classroom approach on college student academic involvement. International Journal of Teaching and Learning in Higher Education, 27(1), 42-55.

McKernan, J. (1991). Curriculum action research: A handbook of methods and resources for the reflective practitioner. New York: St. Martin's Press.

Memiş, M., \& Erdem, M. (2013). Methods/usage features that are used in foreign language teaching and critics. Turkish StudiesInternational Periodical for the Languages, Literature and History of Turkish or Turkic, 8(9), 297-318.

MoNE (Ministry of Education). (2017). Ingilizce Dersi Öğretim Programı [English Course Curriculum]. Ankara.

Miles, M. B., \& Huberman, A. M. (1994). Qualitative Data Analysis: An Expanded Sourcebook. (2nd Edt.). Thousand Oaks, California: Sage Publications. 
Ning, H. (2013). The impact of cooperative learning on English as a Foreign Language tertiary learners' social skills. Social Behavior and Personality, 41(4), 557-568.

O'Neil, K., Kelly, T., \& Bone, S. (2012, June). We turned learning on its ear: flipping the developmental classroom. Paper presented at World Conference on Educational Multimedia, Hypermedia and Telecommunications, Chesapeake, VA.

Ökmen, B., \& Kılıç, A. (2016). A research about the level of using language teaching methods and its effect on some variables: in Turkey, Universal Journal of Educational Research, 4(9), 1994-2001.

Ökmen, B., \& Kılıç, A. (2018). English course teaching practices. European Journal of English Language Teaching, 3 (4),65-93.

Ökmen, B., \& Kılıç, A. (2020). The effect of layered flipped learning model on students' attitudes and self-regulation skills. International Journal of Research in Education and Science (IJRES), 6(3), 409-426. DOI: https://doi.org/10.46328/ijres.v0i0.957

Ökmen, B. (2020). Developing the instructional process in layered flipped learning model. (Unpublished Ph. D. dissertation). Düzce University, Institute of Educational Sciences, Düzce.

Özdoğan, E. (2008). İşbirlikli öğrenme yönteminin ilköğretim 4. Sinıf matematik ögrretiminde ögrenci tutum ve başarısına etkisi: bilgisayar destekli işbirlikli öğrenme ve küme destekli bireyselleştirme tekniği [The effect of cooperative learning method on student attitude and achievement in primary school 4th grade mathematics teaching: computer-assisted cooperative learning and cluster-supported individualization technique]. (Unpublished master's thesis). Ege University, İzmir.

Öztürk, S. (2016). Programlama ögretimindeki ters-yüz ögretim yönteminin ögrrencilerin başarılarına, bilgisayara yönelik tutumuna ve kendi kendine öğrenme düzeylerine etkisi [The effect of flipped teaching method in programming teaching on students' achievement, attitude towards computer and self-learning levels]. (Unpublished master's thesis). Ankara University, Ankara.

Paker, T. (2012). Türkiye'de neden yabanc1 dil (ingilizce) öğretemiyoruz ve neden öğrencilerimiz iletişim kurabilecek düzeyde ingilizce öğrenemiyor? [Why do not we teach foreign languages in Turkey and why do not our students learn English at a level that can communicate?]. Pamukkale University Journal of Education, 32, 89-94.

Pala, A. (2006). İlköğretim birinci kademe öğretmenlerinin eğitim teknolojilerine yönelik tutumları [Primary school teachers' attitudes towards educational technologies]. Journal of Manas University Social Sciences, 16, 177-188.

Sirakaya, D. A. (2017). Student Views on Gamified Flipped Classroom Model. Ondokuz Mayls University Journal of Education Faculty, 36(1), 114-132.

Snow, C. E. (2002). Reading for understanding toward an RveD program in reading comprehension. Pittsburg: RAND.

Şahin, Ş., Boyacı, Z., Ökmen, B., Danişman, Ş., Hasırcı Eriş, H. M., \& Kılıç, A. (2020). Determining Visions Related to the Flipped Learning. Manisa Celal Bayar University Journal of Social Sciences, 18 (3), 62-84. https://doi.org/10.18026/cbayarsos.600312.

Talbert, R. (2012). Inverted classroom. Colleagues, 9(1).

Tétreault, P. L. (2006). The flipped classroom: Cultivating student engagement (Unpublished master dissertation). University of Victoria, Kanada.

Thoms, C. L. (2012). Enhancing the blended learning curriculum by using the "flipped classroom" approach to produce a dynamic learning environment. Iceri2012 Proceedings, 2150-2157.

Topaloğlu, Y. (2012). Erken yaşta yabancı dil ögrretiminde yöntem ve tekniklerin kullanım sorunsall, Çukurova üniversitesi [The problem of using methods and techniques in 
foreign language teaching at an early age, Çukurova University]. (Unpublished master's thesis). Çukurova University, Adana.

Turan, Z., \& Göktaş, Y. (2015). A new approach in higher education: The students' views on flipped classroom method. Journal of Higher Education \& Science/Yüksekögretim ve Bilim Dergisi, 5(2), 156-164. 